\title{
SOCIEDADE, COTIDIANO ESCOLAR E CULTURA(S): UMA APROXIMAÇÃO*
}

\author{
Vera Maria Ferrāo Candau ${ }^{* *}$
}

\begin{abstract}
RESUMO: Este trabalho pretende apresentar a problemática da educação multicultural hoje, do ponto de vista conceitual e prático. Neste contexto, situa e define a perspectiva da educação intercultural Apresenta uma visão de conjunto da linha de pesquisa que a autora vem desenvolvendo no Departamento de Educação da PUC-Rio, que tem por preocupação central analisar as relações entre cultura(s) e educação na sociedade brasileira.
\end{abstract}

Palavras-chave: Multiculturalismo. Interculturalismo. Cultura(s). Cotidiano escolar.

\section{SOCIETY, EVERYDAY SCHOOL LIFE AND CULTURE(S): AN APPROACH}

ABSTRACT: This paper analyses the current multicultural education both from a theoretical and a practical point of view. Using multicultural education as a frame of reference, it also defines the notion of intercultural education. Finally, it presents a general view of the research being carried out by the author at the Department of Education of the Catholic University of Rio de Janeiro (PUC-Rio). The project is mainly concerned with the discussion of the relationship between culture(s) and education in the Brazilian society.

Key words: Multiculturalism. Interculturalism. Culture(s). School practices.

\footnotetext{
Este texto é uma versão revista e ampliada do trabalho Multiculturalismo, cotidiano escolar e formação de professores, apresentado no Colóquio sobre Questôes Curriculares, realizado na Universidade do Minho, Portugal, de 4 a 6 de fevereiro de 2002, e promovido por essa instituição e pela Universidade Federal do Rio de Janeiro (UFRJ).

** Professora titular e pesquisadora do Departamento de Educação da Pontifícia Universidade Católica do Rio de Janeiro (PUC-Rio). E-mail: vmfc@edu.puc-rio.br
} 

questão multicultural nos últimos anos vem adquirindo cada vez maior abrangência, visibilidade e conflitividade, no âmbito internacional e local. Isso preocupa muitas sociedades. $\mathrm{O}$ debate é intenso nos Estados Unidos e também na Europa. Não se trata de maximizar a dimensão cultural e desvinculá-la das questões de caráter estrutural e da problemática da desigualdade e da exclusão crescentes no mundo atual, nem de considerá-la um mero subproduto desta realidade. O importante é, tendo presente a configuração político-social e ideológica do momento, não negar a especificidade da problemática cultural, sem considerá-la de modo isolado e autocentrado.

$\mathrm{Na}$ América Latina e, particularmente, no Brasil, a questão multicultural apresenta uma configuração própria. Nosso continente é um continente construído com uma base multicultural muito forte, onde as relações interétnicas têm sido uma constante através de toda sua história, uma história dolorosa e trágica principalmente no que diz respeito aos grupos indígenas e afro-descendentes.

A nossa formação histórica está marcada pela eliminação física do "outro" ou por sua escravização, que também é uma forma violenta de negação de sua alteridade. Os processos de negação do "outro" também se dão no plano das representações e no imaginário social. Neste sentido, o debate multicultural na América Latina coloca-nos diante desses sujeitos históricos que foram massacrados, que souberam resistir e continuam hoje afirmando suas identidades fortemente na nossa sociedade, mas numa situação de relações de poder assimétricas, de subordinação e acentuada exclusão.

No plano nacional, convém salientar que, pela primeira vez na nossa história, uma proposta educacional que emana do Ministério de Educação nacional, os Parâmetros Curriculares Nacionais, publicados em 1997 e que suscitaram grandes controvérsias quanto a sua concepção, processo de construção e estruturação interna, incorporou, entre os temas transversais, o da pluralidade cultural. Esta opção não foi pacífica e sim objeto de controvérsias, de toda uma negociação em que a pressão dos movimentos sociais se fez presente, e a reestruturação da equipe responsável, inevitável. O próprio documento assim justifica a introdução da temática da pluralidade cultural no currículo escolar:

É sabido que, apresentando heterogeneidade notável em sua composição populacional, o Brasil desconhece a si mesmo. Na relação do País consigo mesmo, é comum prevalecerem vários estereótipos, tanto regionais quanto em relação a grupos étnicos, sociais e culturais. 
Historicamente, registra-se dificuldade para se lidar com a temática do preconceito e da discriminação racial/étnica. O País evitou o tema por muito tempo, sendo marcado por "mitos" que veicularam uma imagem de um Brasil homogêneo, sem diferenças, ou, em outra hipótese, promotor de uma suposta "democracia racial". (Parâmetros Curriculares Nacionais, vol. 10, p. 22)

Por outro lado, somos conscientes de que o atual contexto internacional, marcado por uma globalização excludente, políticas neoliberais e uma emergente doutrina de segurança global, está reforçando fenômenos socioculturais de verdadeiro apartheid, que assumem diferentes formas e manifestações. No entanto, esta não é uma realidade que afeta igualmente a todos os grupos sociais, culturais, nem a todas as pessoas. São os considerados "diferentes", aqueles que por suas características sociais e/ ou étnicas, por serem considerados "portadores de necessidades especiais", por não se adequarem a uma sociedade cada vez mais marcada pela competitividade e pela lógica do mercado e do consumo, os "perdedores", os "descartáveis", que vêm a cada dia negado o seu "direito a ter direitos" (Hanna Arendt).

É exatamente nesta conjuntura que a UNESCO, logo após a realização da controvertida Conferência da ONU sobre o "Racismo, a Discriminação Racial, a Xenofobia e as Formas Conexas de Intolerância", realizada em Durban (Africa do Sul), do 31 de agosto ao 8 de setembro de 2001, em sua última Conferência Geral, celebrada em Paris, de 15 de outubro a 3 de novembro de 2001, aprovou por aclamação uma Declaração Universal sobre a Diversidade Cultural. Nessa ocasião, o Diretor-Geral deste organismo, Koïchiro Matsuura, afirmou que esperava que essa declaração chegasse "um dia a adquirir tanta força quanto a Declaração Universal dos Direitos Humanos".

É neste horizonte que se coloca o presente trabalho, que tem por objetivo apresentar uma visão de conjunto da linha de pesquisa que vimos desenvolvendo, desde 1996, com o apoio do Conselho Nacional de Desenvolvimento Científico e Tecnológico (CNPq) e, nos últimos dois anos, da Fundação de Amparo à Pesquisa do Rio de Janeiro (FAPERJ), no Departamento de Educação da PUC-Rio, tendo como preocupação central as relações entre cultura(s) e educação na sociedade brasileira.

\section{Algumas tensões fundamentais}

O referencial teórico que vimos trabalhando ao longo desses anos, tentando navegar na ampla literatura sobre o tema, tem privilegiado algumas tensões que consideramos especialmente significativas no mundo 
atual e mergulhado nas diferentes concepções e propostas do multiculturalismo. Permeando toda nossa reflexão está o aprofundamento em conceitos especialmente complexos e polissêmicos, tais como cultura, identidade cultural, diferença, diversidade cultural, identidades de fronteira, hibridização cultural, entre outros. Trata-se de um universo semântico amplo no qual seria impossível aprofundar-se neste momento. Limitar-nos-emos a tecer algumas considerações que permitam explicitar a perspectiva em que nos situamos.

No que diz respeito às tensões, privilegiamos três que se interpenetram e que consideramos fundamentais para as questôes educativas: globalização versus multiculturalismo, igualdade versus diferença e universalismo versus relativismo cultural .

Globalização e multiculturalismo muitas vezes são apresentados como movimentos com lógicas contrapostas. A primeira reforçando a padronização e o segundo as particularidades culturais e as diferenças. No entanto, estas relações se revelam de grande complexidade, não podendo ser vistas de modo simplificado e reducionista, assumindo diferentes configuraçōes. Partindo das contribuições de Stuart Hall (1997a; 1997b) e Boaventura de Sousa Santos (2001), procuramos penetrar nas teias que configuram tais relações numa perspectiva dialética e multidimensional.

Articular igualdade e diferença constitui outra questão que permeia todo o nosso trabalho. No entanto, o problema não é afirmar um pólo e negar o outro, mas sim termos uma visão dialética da relação entre igualdade e diferença. Hoje em dia não se pode falar em igualdade sem incluir as questôes relativas à diferença, nem se pode abordar temas relativos às políticas de identidade dissociadas da afirmação da igualdade.

Uma frase de Sousa Santos (2001) sintetiza de maneira especialmente oportuna esta tensão: "As pessoas e os grupos sociais têm $o$ direito a ser iguais quando a diferença os inferioriza, e o direito a ser diferentes quando a igualdade os descaracteriza". E acrescenta: "Este é, consabidamente, um imperativo muito difícil de se atingir e manter" (p. 10).

Não se deve contrapor igualdade à diferença. De fato, a igualdade não está oposta à diferença, e sim à desigualdade, e diferença não se opõe à igualdade e sim à padronização, à produção em série, à uniformidade, a sempre o "mesmo", à "mesmice".

O que estamos querendo trabalhar é, ao mesmo tempo, negar a padronização e também lutar contra todas as formas de desigualdade e discriminação presentes na nossa sociedade. Nem padronização nem desigualdade. A igualdade que queremos construir assume o reconhe- 
cimento dos direitos básicos de todos. No entanto, esses todos não são padronizados, não são os "mesmos". Têm que ter as suas diferenças reconhecidas como elementos presentes na construção da igualdade.

Considero que, nos próximos anos, essa temática vai suscitar uma grande discussão, um debate difícil, que desperta muitas paixões, mas que é fundamental para se avançar na afirmação da democracia. Hoje em dia não se pode mais pensar numa igualdade que não incorpore o tema do reconhecimento das diferenças, o que supõe lutar contra todas as formas de desigualdade, preconceito e discriminação.

A terceira tensão, universalismo versus relativismo cultural, é especialmente relevante para a ação educativa e, particularmente, para as questôes curriculares. A escola como instituição está construída tendo por base a afirmação de conhecimentos e valores considerados universais, uma universalidade muitas vezes formal que, se aprofundarmos um pouco, termina por estar assentada na cultura ocidental e européia, consideradas como portadoras da universalidade. A questão colocada hoje supõe perguntarmo-nos e discutirmos que universalidade é essa, mas, ao mesmo tempo, não cairmos num relativismo absoluto, reduzindo a questão dos conhecimentos e valores veiculados pela escola a um determinado universo cultural, o que nos levaria inclusive a negar a própria possibilidade de construirmos algo juntos, negociado entre os diferentes, e à guetificação. A questão do conhecimento e dos valores transculturais, preferimos esta expressão, faz com que nos situemos de uma maneira crítica em relação aos conhecimentos e valores universais tal como estamos acostumados a considerá-los, assim como em relação ao relativismo cultural radical.

Não estaremos chamados a relativizar o universalismo, afirmando seu caráter histórico e dinâmico, e, ao mesmo tempo, a relativizar o relativismo, afirmando seu caráter não absoluto, atentos aos "meta-valores", aos conteúdos transculturais, historicamente construídos? (Candau, 2000, p. 83)

Este tema começa a ser objeto de uma ampla discussão entre os educadores e pesquisadores das áreas de currículo e didática, assim como de filosofia e sociologia da educação.

\section{Multiculturalismo ou Multiculturalismos?}

O tema do multiculturalismo é especialmente polêmico no momento atual. Defensores e críticos confrontam suas posições apaixonadamente. Uma das características fundamentais deste possível campo de estudos constituído pelas questões multiculturais é exatamente o fato de 
estar atravessado pelo acadêmico e o social, a produção de conhecimentos e a militância. Convém ter sempre presente que o multiculturalismo não nasceu nas universidades e no âmbito acadêmico em geral. São as lutas dos grupos sociais discriminados e excluídos de uma cidadania plena, os movimentos sociais, especialmente os referidos às questóes identitárias, que constituem o locus de produção do multiculturalismo. Sua penetração na academia deu-se num segundo momento e, até hoje, me atreveria a afirmar, sua integração no mundo universitário é frágil e objeto de muitas discussões, talvez exatamente por seu caráter profundamente marcado pela intrínseca relação com a dinâmica dos movimentos sociais. Não é possível trabalhar questôes relativas ao multiculturalismo sem um diálogo intenso com os grupos sociais, relação esta que passa por algum tipo de presença nos diferentes fóruns da sociedade em que os conflitos e embates multiculturais se dão. Neste sentido, o multiculturalismo não pode ser reduzido a uma temática de produção acadêmica. Ao mesmo tempo em que penetra na lógica da academia, submete-a permanentemente a vários questionamentos a partir do "olhar" e do compromisso da militância.

Outra dificuldade para se penetrar na problemática do multiculturalismo está referida à polissemia do termo. Inúmeras e diversificadas são as concepções e vertentes multiculturais. Muitos autores, tanto de perspectiva liberal quanto de inspiração marxista, que levantam fortes questionamentos teóricos e ao seu papel na sociedade, não levam devidamente este fato em consideração ou, quando o fazem, referem-se a aspectos mais superficiais, sem distinguirem com maior profundidade as diferentes posiçōes, ou fazem grandes generalizaçôes.

No que diz respeito às diferentes concepções e propostas do multiculturalismo, esta corrente de pensamento tem sido reconhecida e discutida por defensores e críticos, como uma estratégia de lidar com as diferenças, seja no âmbito político-social, cultural ou educativo.

Nos Estados Unidos, Peter McLaren e James Banks são dois importantes autores que abordam a questão do multiculturalismo a partir da realidade americana. $\mathrm{O}$ ambiente escolar nesse país tem se tornado palco de diversas tragédias ligadas muitas vezes às questóes étnicas. Nesse contexto, o debate sobre a educação multicultural tornase especialmente intenso, sendo protagonizado tanto por grupos mais conservadores, que o apontam como uma nova forma de racismo, quanto por aqueles que o concebem como um princípio orientador da educação para a democracia em um mundo marcado pela globalização e pelo pluralismo cultural. 
Ancorado na Pedagogia Crítica, McLaren nos últimos anos vem trabalhando também questôes hoje colocadas pela chamada perspectiva pós-moderna. Em relação ao multiculturalismo como projeto político, enumera quatro grandes tendências: multiculturalismo conservador, multiculturalismo humanista liberal, multiculturalismo liberal de esquerda e multiculturalismo crítico. Embora proponha essas quatro tendências, reconhece que as características de cada posição tendem a se misturar umas com as outras dentro do horizonte geral da vida social. Parte da afirmação de que a descrição que faz dos diversos tipos de multiculturalismo tem exclusivamente um papel heurístico, já que as diferentes posições se interpenetram nas práticas sociais.

Começa por identificar um multiculturalismo que chama de conservador ou empresarial, que pode assumir diferentes formas: as visões coloniais de europeus e norte-americanos em relação aos povos colonizados encarados como escravos, serviçais etc., as teorias evolucionistas que justificaram políticas imperialistas, assim como pode também ser encarado como resultado direto das políticas de supremacia branca. Esta posição defende o projeto de construir uma cultura comum e, em nome dele, deslegitima dialetos, saberes, línguas, crenças, valores "diferentes", pertencentes aos grupos subordinados, considerados inferiores. Querem assimilar a todos à ordem social dominante. "Um pré-requisito para juntar-se à turma é desnudar-se, desracializar-se, e despir-se de sua própria cultura" (p. 115). Para McLaren esta não é uma posição superada. Pelo contrário, apresenta muitas manifestaçôes e vigor na sociedade norteamericana atualmente. Para qualquer observador atento é fácil identificar fenômenos que atestam sua forte presença hoje na escala planetária.

Uma segunda posição é a que denomina de multiculturalismo humanista liberal. Parte da afirmação da igualdade intelectual entre diferentes etnias e grupos sociais, o que permite a todos competir na sociedade capitalista. Para que esta competição se possa dar, é necessário remover os obstáculos por meio de reformas orientadas a melhorar as condições econômicas e socioculturais das populações dominadas. Para tal, podem ser criados programas específicos, dentro do modelo social vigente. Essa posição, segundo o autor, reveste-se freqüentemente de um humanismo etnocêntrico e universalista que privilegia na realidade os referentes dos grupos dominantes.

Quanto ao multiculturalismo liberal de esquerda, coloca a ênfase na diferença cultural e afirma que privilegiar a igualdade entre as raças/ etnias pode abafar diferenças culturais importantes entre elas, assim como as diferenças de gênero, classe social e sexualidade. No entanto, segundo 
McLaren, esta posição pode tender a essencializar as diferenças e não ter presente que estas são construçôes históricas e culturais, permeadas por relaçôes de poder. Favorece muitas vezes também um certo elitismo populista que valoriza as experiências dos grupos populares e étnicos e praticamente não leva em consideração a cultura dominante.

A última posição assinalada pelo autor, tendência na qual se situa, é a que ele mesmo denomina de multiculturalismo crítico (1997) e, mais recentemente, multiculturalismo revolucionário (2000).

Esta perspectiva parte da afirmação de que o multiculturalismo tem de ser contextualizado a partir de uma agenda política de transformação, sem a qual corre o risco de se reduzir a outra forma de acomodação à ordem social vigente. Entende as representaçóes de raça, gênero e classe como produtos de lutas sociais sobre signos e significaçôes. Privilegia a transformação das relações sociais, culturais e institucionais nas quais os significados são gerados. Recusa-se a ver a cultura como não-conflitiva, argumenta que a diversidade deve ser afirmada "dentro de uma política de crítica e compromisso com a justiça social” (p. 123). Entende o educador como agente revolucionário, ressaltando que se reconhecer dessa forma

é mais do que um ato de compreender quem somos; é um ato de reivindicação de nós mesmos a partir de nossas identificações culturais sobrepostas e de nossas práticas sociais, de forma que possamos vinculá-las à materialidade da vida social e às relações de poder que as estruturam e as sustentam. (McLaren, 2000, p. 2)

Este enfoque se recusa a entender a cultura como não-conflitiva, harmoniosa ou consensual. Para ele, as questóes relativas à diferença são determinadas pelos processos históricos, pelas mentalidades e ideologias, pelas relaçóes de poder e mobilizam processos políticos e sociais.

Outro autor do cenário norte-americano, profundamente envolvido com a questão das relações entre multiculturalismo e educação e que assume uma perspectiva de caráter liberal, é James A. Banks (1999). Esse autor parte sua análise da problemática do fracasso escolar dos alunos oriundos das camadas populares e, particularmente, de grupos étnicos como os afro-descententes. Privilegia na sua análise dois paradigmas utilizados para enfrentar essa problemática. $\mathrm{O}$ primeiro, da privação cultural, parte do pressuposto de que o fracasso desses alunos está motivado pela cultura em que foram socializados, que não lhes favoreceu experiências fundamentais para o bom desempenho escolar. Os defensores desta perspectiva consideram o contexto social e a cultura de origem dos alunos como o maior problema e não a cultura 
da escola. Neste sentido, privilegiam estratégias educacionais de "compensação" das deficiências culturais dos alunos. Pode-se dizer que esse paradigma reconhece a diversidade cultural mas hierarquiza as diferentes culturas, considerando a relação entre elas de superior a inferior. Desvaloriza determinadas culturas e suas especificidades e reduz o papel da educação a uma função de compensação cultural que termina por negar a diferença.

Quanto ao segundo paradigma, que Banks intitula da diferença cultural, parte da afirmação de que as diferentes culturas possuem linguagens, valores, símbolos e estilos de comportamentos diferentes, que têm de ser compreendidos na sua originalidade. As relaçôes entre as culturas não podem ser analisadas numa perspectiva hierarquizadora. Neste sentido, os seus defensores, entre os quais se situa, opóem-se ao primeiro paradigma e deslocam o centro da questão. O que precisa ser mudado não é a cultura do aluno, mas a cultura da escola, que é construída com base em um único modelo cultural, o hegemônico, apresentando um caráter monocultural.

$\mathrm{Na}$ visão de Banks, a educação multicultural é um movimento reformador destinado a realizar grandes mudanças no sistema educacional. Concebe como a principal finalidade da educação multicultural favorecer que todos os estudantes desenvolvam habilidades, atitudes e connhecimentos necessários para atuar no contexto da sua própria cultura étnica, no da cultura dominante, assim como para interagir com outras culturas e situar-se em contextos diferentes dos de sua origem (Banks, 1999, p. 2).

Banks (1994) afirma que existem diversas formas de abordar a questão das relações entre educação e cultura(s) no contexto escolar. Assim, identifica dez modelos que permeiam os programas e as práticas escolares sob o mesmo rótulo de educação multicultural: étnico-aditivo, de desenvolvimento do autoconceito, da privação cultural, centrado na linguagem, anti-racista, radical, baseado na meritocracia, assimilacionista, do pluralismo cultural e da diferença cultural.

Propõe um modelo próprio de educação multicultural para ser um referente no dia-a-dia das salas de aula, baseado em cinco dimensões interligadas, que assim são explicitadas (Banks, 1999):

- Integração de conteúdo: lida com as formas pelas quais os professores usam exemplos e conteúdos provenientes de culturas e grupos variados para ilustrar os conceitos-chave, os princípios, as generalizações e teorias nas suas disciplinas ou áreas de atuação; 
- processo de construção do conhecimento: propõe formas por meio das quais os professores ajudam os alunos a entender, investigar e determinar como os pressupostos culturais implícitos, os quadros de referência, as perspectivas e os vieses dentro de uma disciplina influenciam as formas pelas quais o conhecimento é construído;

- pedagogia da eqüidade: existe quando os professores modificam sua forma de ensinar de maneira a facilitar o aproveitamento acadêmico dos alunos de diversos grupos sociais e culturais, o que inclui a utilização de uma variedade de estilos de ensino, coerentes com a diversidade de estilos de aprendizagem dos vários grupos étnicos e culturais;

- redução do preconceito: esta dimensão focaliza atitudes dos alunos em relação à raça e como elas podem ser modificadas por intermédio de métodos de ensino e determinados materiais e recursos didáticos;

- uma cultura escolar e estrutura social que reforcem o empoderamento de diferentes grupos: promove um processo de reestruturação da cultura e organização da escola, para que os alunos de diversos grupos étnicos, raciais e sociais possam experimentar a eqüidade educacional e o reforço de seu poder na escola.

Para Banks \& Banks (1997), a educação multicultural deve ser entendida como um conceito complexo e multidimensional. Afirmam que se costuma focalizar apenas uma de suas dimensóes, reduzindo-a. $\mathrm{Na}$ escola esta visão reducionista se evidencia pelo entendimento do multiculturalismo como apenas a inclusão de contribuições de diferentes grupos étnicos no currículo, ou a redução do preconceito ou a celebração de festas relacionadas às diferentes culturas. Na visão de educação multicultural proposta por Banks, a ênfase não é no ou, mas sim no e. Assim, cada atividade que pretenda trabalhar a perspectiva multicultural é importante na medida em que esteja integrada numa proposta ampla, ou seja, que não se constitua em uma iniciativa isolada.

Outro aspecto que esse autor trabalha se relaciona às estratégias utilizadas para se transformar o currículo na perspectiva da introdução da sensibilidade à diversidade cultural. Distingue quatro abordagens que podem indicar diferentes níveis de mudança curricular. O nível mais elementar é o que enfatiza, sem afetar o currículo formal, as contribuiçōes das diferentes culturas por meio da introdução no cotidiano escolar de 
comemorações, eventos e realização de acontecimentos específicos relativos às diversas culturas. A abordagem aditiva procura penetrar o currículo formal acrescentando determinados conteúdos em diferentes disciplinas sem afetar a sua estrutura básica. $\mathrm{O}$ enfoque transformador, em contraste com o aditivo, reestrutura o currículo em sua própria lógica de base, de modo a permitir que os estudantes trabalhem conceitos, temas, fatos etc., provenientes de diferentes tradições culturais e, o quarto enfoque, da ação social, estende a transformação curricular à possibilidade de desenvolver projetos e atividades que suponham envolvimento direto e compromisso com diferentes grupos culturais, favorecendo a relação teoria/prática no que diz respeito à diversidade cultural.

Uma das questões que consideramos fundamental é a colocada por Garcia Castaño, Pulido e Montes del Castillo (1998), antropólogos que trabalham nos Laboratorios de Estudios Interculturales das universidades de Granada, Almeria e Murcia (Espanha), respectivamente, os quais sustentam que, tendo presente que por detrás de cada modelo de educação multicultural existe um conceito de cultura, o problema está em que, na maior parte das vezes, esse conceito não está explícito. No entanto, devemos "desvelá-lo" para entender o sentido profundo da proposta pois, em geral, a concepção de cultura predominante nas propostas de educação multicultural aproxima-se de uma perspectiva estática e essencialista, em que a cultura é vista como um conjunto mais ou menos definido de características estáveis atribuídas a diferentes grupos e às pessoas que se considera a eles pertencerem. Esta é uma realidade muito presente no imaginário dos educadores e da sociedade em geral, que tendem a classificar as pessoas segundo atributos considerados específicos de determinados grupos sociais. Questionar esta perspectiva é um grande desafio.

No nosso trabalho de pesquisa, tendo presente as diferentes posições existentes no campo da educação multicultural, privilegiamos a abordagem da educação intercultural, que parte de um conceito dinâmico e histórico da(s) cultura(s), como processo em contínua construção, desconstrução e reconstrução, no jogo das relações sociais presentes nas sociedades. Neste sentido, a cultura não é, está sendo a cada momento. $\mathrm{O}$ interculturalismo, ainda pouco trabalhado pela literatura brasileira, supõe a deliberada inter-relação entre diferentes grupos culturais. Neste sentido, situa-se em confronto com todas as visões diferencialistas que favorecem processos radicais de afirmação de identidades culturais específicas. Rompe com uma visão essencialista das culturas e das identidades culturais. Parte da afirmação de que nas 
sociedades em que vivemos os processos de hibridização cultural são intensos e mobilizadores da construção de identidades abertas, em construção permanente. É consciente dos mecanismos de poder que permeiam as relações culturais. Não desvincula as questóes da diferença e da desigualdade presentes na nossa realidade e no plano internacional. A abordagem intercultural que assumimos se aproxima do multiculturalismo crítico de McLaren (1997; 2000).

Pela importância, no nosso trabalho, do conceito de hibridização cultural, gostaríamos de explicitar os principais autores que nos servem de referência. São eles Stuart Hall (1997a; 1997b) e Garcia Canclini (1991; 1995; 1997; 1999), especialistas que vêm abordando esta temática desde diferentes perspectivas. Garcia Canclini é particularmente enfatizado por aprofundar a reflexão sobre esses processos na perspectiva da problemática latino-americana. Para este autor,

Estabelecer relações entre as estratégias globalizadoras e de hibridização e as experiências variadas de interculturalidade torna visível que, por mais que se forme um mercado mundial de finanças, de alguns bens e alguns circuitos mediáticos, por mais que avance o inglês como "língua universal", subsistem as diferenças e a tradutibilidade entre as culturas é limitada. Não é impossível. Superando as narrativas fáceis da homogeneização absoluta e da resistência do local, a globalização nos confronta com a possibilidade de apreender fragmentos, nunca a totalidade, de outras culturas e reelaborar o que vínhamos imaginando como próprio em interaçóes e acordos com outros, nunca com todos. Deste modo a oposição já não é entre o global e o local, entendendo global como subordinação geral a um único estereótipo cultural, ou local simplesmente como diferença. A diferença não se manifesta como compartimentalização de culturas separadas e sim como interlocução com aqueles com que estamos em conflito ou buscamos alianças. (Garcia Canclini, 1999, p. 123)

\section{O caminho percorrido}

No período de 1996 até o presente momento desenvolvemos três projetos integrados de pesquisa, com a participação de alunos de graduação e pós-graduação, assim como produzimos vários artigos, capítulos de livros e orientamos dissertações de mestrado e teses de doutorado que abordam diferentes dimensões das relações entre multiculturalismo e educação.

No que diz respeito aos projetos integrados de pesquisa, o primeiro, intitulado "Cotidiano escolar e cultura(s): Desvelando o dia-a-dia....", desenvolvido de março de 1996 a fevereiro de 1998, teve como objetivo 
geral compreender como se dão no cotidiano escolar as relações entre educação e cultura(s), como se expressam as diferentes dimensóes desta problemática no dia-a-dia das escolas. $\mathrm{O}$ estudo realizado caracterizou-se por seu caráter exploratório, procurando enfatizar uma visão ampla e geral da temática.

O trabalho de campo foi realizado em duas escolas de ensino médio, situadas na mesma área geográfica do Rio de Janeiro, a zona sul da cidade. Dada a natureza das questões que nortearam o trabalho, consideramos mais adequado delimitar o campo da investigação ao ensino médio. Outra razão que justificou esta opção é a pouca atenção que as escolas desse nível de ensino têm tido nas pesquisas sobre cotidiano escolar.

A escolha por se trabalhar com duas escolas obedeceu ao desejo de investigar as relações entre escola e cultura(s) em contextos escolares que lidam com diferentes tipos de clientela. A hipótese de trabalho que orientou a seleção das escolas foi assim formulada:

a escola lida sempre com dificuldade com a diferença e o pluralismo sóciocultural. Existe sempre uma ruptura entre a cultura escolar/cultura da escola e o universo cultural da sua clientela. No entanto, esta tensão e/ou conflito se manifesta de diferentes maneiras, tem "rostos" distintos, na escola pública e na escola particular.

Para verificar esta suposição, o trabalho de campo foi realizado em duas escolas que, situadas no mesmo contexto geográfico, dirigiam-se a populações provenientes de universos sociais e culturais nitidamente diferenciados e mesmo, particularmente no atual contexto da cidade do Rio de Janeiro, uma "cidade partida", na expressão de Zuenir Ventura, em situação diária de confronto.

As duas escolas escolhidas, Colégio Guarani e Escola Iracema, ${ }^{1}$ a primeira uma escola pública estadual de ensino médio e a segunda uma escola particular que desenvolve sua ação educativa do pré-escolar ao ensino médio, são conhecidas na sociedade carioca como escolas "diferentes", em função principalmente do seu passado de caráter "alternativo" e da sua preocupação com a qualidade do ensino e a relação com a atualidade.

No estudo realizado, penetramos no cotidiano de cada uma das escolas de modo progressivo, intensivo e abrangente; na sala de aula, nas atividades extra-classe, sempre atentos às diversas dimensões da prática pedagógica. O "olhar" de inspiração antropológica foi privilegiado.

Nas duas escolas foram observados(as) professores(as) de disciplinas das áreas curriculares de Ciências Sociais e Ciências Naturais, além da 
disciplina de Língua Portuguesa, considerada indispensável dada a natureza do estudo.

O estudo focalizou turmas de primeiro e segundo ano do ensino médio, já que o terceiro ano apresenta uma problemática muito específica, quer seja pela proximidade do vestibular e/ou do término da escolarização e de seus possíveis desdobramentos em relação ao mercado de trabalho.

Quanto às atividades extra-classe, procuramos participar do cotidiano da escola em suas diferentes atividades, desde o corredor e o recreio, até as diferentes comemoraçôes e festas, assim como de conselhos de classe, reuniōes de professores(as), de reflexão pedagógica, de planejamento etc. Foi dada particular atenção às atividades de iniciativa dos alunos e alunas ou nas quais sua participação era especialmente significativa.

As principais técnicas utilizadas na pesquisa foram: análise documental, observação e entrevista. A análise documental incluiu a consulta de documentos oficiais - registros, atas de reunião, planificaçôes, grades curriculares, diários de classe, planos de aula, livros-texto e outros materiais didáticos, boletins, dados estatísticos da escola, cartas oficiais, circulares etc. -, assim como de documentos pessoais - exercícios dos alunos, diários, "grafites", desenhos, notas pessoais etc.

No Colégio Guarani, o número total de horas de observação foi de, aproximadamente, 215 e, na Escola Iracema, de 220 horas. Quanto às entrevistas, foram realizadas com a direção, coordenadores(as), professores(as) e alunos(as) das respectivas escolas. No Colégio Guarani foram entrevistados 24 profissionais da educação e 25 alunos(as) e na Escola Iracema, 15 profissionais da educação e 25 alunos(as). As entrevistas foram de caráter semi-estruturado e estavam orientadas a captar os modos de pensar, sentir, situar-se, apreciar etc., dos diferentes agentes educativos em relação às questôes-eixo que orientavam a pesquisa. Os roteiros que serviram de base para essas entrevistas passaram por um longo processo de discussão e construção coletiva por parte de toda a equipe. Além das entrevistas individuais, no caso dos(as) alunos(as), optamos por também realizar o que chamamos "Encontros de Opinião", uma modalidade de entrevista coletiva com uma dinâmica proposta para cada encontro, de modo que se favoreceu o diálogo entre os(as) jovens sobre alguns temas de particular relevância para a pesquisa. Em cada uma das escolas foram realizados quatro encontros sobre os seguintes temas: "E os jovens hoje?", "Iguais ou diferentes?", "A escola: Realidade e sonho" e "Violência hoje". 
A realização da pesquisa permitiu levantar algumas questóes e detectar desafios importantes para a construção de práticas educativas relevantes, capazes de dialogar com as transformações socioculturais presentes na nossa sociedade. Destacaremos alguns aspectos.

Uma questão básica, que perpassou todo o trabalho realizado, está referida ao próprio sentido da escolarização na sociedade atual e, mais concretamente, ao papel do ensino médio. Tendo-se presente a afirmação de Perez Gomez (1993) de que a escola deveria ser concebida como um espaço de cruzamento de culturas e exercer uma função de mediação reflexiva daquelas influências plurais que as diferentes culturas exercem de forma permanente sobre as novas geraçōes (p. 80), o universo escolar pesquisado revelou-se bastante longe desta possibilidade. Em linhas gerais, apresentou-se bastante uniforme e auto-referido, distante de ser um espaço dinâmico e plural, que favorece o diálogo entre diferentes culturas.

No caso das escolas pesquisadas, além da sua uniformidade, apesar da diferenciação da clientela das escolas, ficou evidente a falta de clareza sobre o sentido do ensino médio hoje e suas funçóes. Cruzaram-se diferentes expectativas e movimentos. Para uns, o fundamental é a preparação para o vestibular. Para outros, este ensino está orientado unicamente para uma terminalidade formal, para a "certificação". Também foi expresso o desejo de uma melhor preparação para o mercado de trabalho, além de, na perspectiva dos alunos, ser concebido como um espaço de socialização e lazer. De fato, educadores e alunos não pareciam ter clareza sobre a identidade da escola de ensino médio hoje na nossa sociedade, quais deveriam ser suas preocupações fundamentais e que novas funções deveriam ser incorporadas.

Junto com esta questão e em íntima relação com ela, pode também ser colocada a questão da importância e, ao mesmo tempo, da dificuldade de se construir um projeto pedagógico para as escolas de ensino médio. As experiências analisadas tornaram muito evidente que este aspecto deve ser muito mais valorizado no âmbito escolar. O projeto pedagógico confere identidade, impregna a cultura escolar e a cultura da escola, favorece a coesão e um sentido de pertença que dão consistência ao processo educativo. Ambas as escolas experimentaram esta realidade nas suas origens, mas a proposta foi se diluindo com o passar dos anos. No entanto, ainda hoje, por afirmação de alguns de seus elementos ou pela consciência de sua ausência, constatou-se o poder mobilizador de sonhos, análises críticas e perspectivas de futuro do projeto pedagógico. 
A pesquisa realizada permitiu-nos, ainda que com caráter exploratório, penetrar nos meandros e na complexidade dos processos que constituem a cultura escolar (Forquin, 1993). Consideramos a sala de aula como o espaço privilegiado de expressão da cultura escolar. Neste sentido, constatamos que esta manifestava com força uma dinâmica de normatização e rotinização que lhe dava uma acentuada rigidez e pouca permeabilidade a aspectos relacionados à cultura social de referência, assim como a interesses mais conjunturais e contextualizados que emergiam no seu dia-a-dia. Esta realidade nos fez refletir sobre a natureza da cultura escolar e sua relação com o contexto sociocultural em que se situa. Tomar distância da(s) cultura(s) social(ais) de referência será uma exigência para que a escola possa se concentrar na socialização dos conhecimentos considerados universais e gerais, inerentes ao saber escolar? Como articular estes dois movimentos, de garantir o conhecimento escolar e não desconhecer ou negar os saberes sociais de referência? A tendência evidenciada, no nível da sala de aula, privilegiava a distância, a ruptura e, em alguns casos, a negação explícita dos saberes sociais.

Por outro lado, no caso das escolas de ensino médio pesquisadas, é possível afirmar que a seleção dos conteúdos por elas veiculados nas salas de aula estava centrada nos conteúdos definidos para os exames vestibulares e nos livros didáticos adotados, principalmente na escola particular. No caso da escola pública, a seleção estava centrada basicamente nas apostilas indicadas e/ou nos livros didáticos adotados, sem que a referência ao vestibular fosse forte, em geral por não se acreditar nas possibilidades de os alunos terem êxito neste exame. Apesar da afirmação, em ambos os casos, cada vez com maior força, da autonomia das escolas e dos professores, a seleção dos conteúdos veiculados no cotidiano das salas de aula estava muito mais determinada por critérios externos à dinâmica pedagógica escolar.

Outro aspecto importante de ser destacado se relaciona à dificuldade de se articular construção do conhecimento e prazer nesse nível de ensino. A aquisição/construção do conhecimento estava em geral associada a um esforço árido e pouco prazeroso, para o qual a avaliação constituía o estímulo fundamental. Neste sentido, os processos avaliativos ocupavam um lugar privilegiado, enfatizavam-se seus aspectos disciplinadores e de controle, todo esforço sendo mais orientado a "passar" e a "tirar nota" do que a aprender. Em consonância com esta realidade, "dar aula" e "cobrar o conteúdo da aula" constituíam as principais preocupaçôes da grande maioria dos professores. Estamos longe de se conceber a aula como um fórum aberto e democrático de 
diálogo, contraste de abordagens, assim como de se recrear as diferentes perspectivas culturais presentes na nossa sociedade (Perez Gomez, 1993, p. 85).

No entanto, é necessário afirmar que as situações vivenciadas não foram uniformes, admitindo uma gama que ia da ênfase numa visão da prática pedagógica centrada na avaliação, em que o conhecimento se situava de modo funcional em relação a esta, até práticas com maior apelo à criatividade e à construção do conhecimento, em que os processos avaliativos se situavam de modo subordinado e eram abordados de modo mais amplo. No entanto, é possível afirmar que a avaliação é um "nó" especialmente crítico da ação educativa e que, em geral, este era um tema que provocava tensão e desconforto, inibidor de toda tentativa de articulação do conhecimento escolar com outros saberes.

Outro aspecto a destacar em relação à cultura da sala de aula diz respeito à centralidade que nela ocupa a linguagem escrita e oral e sua dificuldade de incorporar, a partir de sua finalidade específica, a pluralidade de novas linguagens hoje presentes na sociedade e com as quais os jovens têm grande familiaridade. Entre as mediações culturais e tecnológicas utilizadas pela escola e aquelas presentes hoje na sociedade e utilizadas pelos diferentes grupos sociais e culturais, existe uma distância bastante acentuada. Certamente um dos desafios em busca de uma escolarização mais em sintonia com os desafios da sociedade atual é repensar a cultura da sala de aula e romper com o "congelamento" que sofreu através do tempo, tanto nos seus aspectos de configuração espaçotemporal, quanto no modo de se conceber e desenvolver o processo de ensino-aprendizagem e as mediações utilizadas, assim como na concepção do(s) saber(es) a ser(em) privilegiado(s) e articulado(s).

Se o espaço privilegiado da cultura escolar é a sala de aula, é possível ter como referência fundamental para a cultura da escola as atividades extra-classe. Estamos conscientes da interpenetração destas duas dimensões - a cultura da escola está presente na cultura escolar e vice-versa - mas, para efeitos da pesquisa de campo, privilegiamos espaços específicos para observar e analisar uma e outra. Se se pode falar da cultura da escola como falamos da cultura da empresa, dos shoppings centers etc., como um mundo social que tem ritmos, ritos, símbolos, linguagens e características próprias (Forquin, 1993, p. 167), certamente ela penetra todos os espaços e tempos escolares. No entanto, partimos da hipótese de que se expressa de modo privilegiado nos espaços menos "controlados" e "rotinizados" que a sala de aula. E neste sentido que privilegiamos a referência às atividades extraclasse para tentar penetrar na cultura da escola. 
Foi possível constatar que estas constituíam realidades plurais, diversificadas, nas quais os alunos tomavam mais iniciativa e se expressavam mais livremente e nas quais se estabeleciam pontes mais espontâneas e dinâmicas com a atualidade, os universos sociais de referência e as culturas dos jovens, mesmo admitindo-se diferentes níveis de tensão entre estas relações. Nessas atividades estavam presentes temas como eleições, olimpíadas e Rio-2004, música popular brasileira, obras teatrais, a reforma agrária e o MST, acontecimentos internacionais, a morte do índio Galdino etc.

Constatamos um contraste especialmente agudo entre a sala de aula e esses espaços e, em geral, os temas presentes nas atividades extra-classe não eram nem reconhecidos, nem valorizados, nem trabalhados na sala de aula. Poucas foram as exceções observadas. Dialetizar a relação sala de aula/ atividades extra-classe parece-nos um caminho particularmente promissor para se estimular a articulação cultura escolar/cultura da escola numa perspectiva de se repensar o papel da escola na nossa sociedade.

O mergulho que realizamos no cotidiano das escolas que participaram dessa pesquisa nos levou a relativizar e problematizar a hipótese que orientou a pesquisa. De fato, na mesma escola, diferentes professores apresentavam modos diversificados de trabalhar a relação escola/cultura(s), indo de um extremo de acentuada ruptura a outro de intensa busca de articulação. No entanto, esta constatação é compatível com a afirmação de que há espaços - as salas de aula - que estão centrados no conhecimento acadêmico e, em geral, apresentam maior distância em relação à(s) cultura(s) social(ais) de referência, e outros - as atividades extra-classe, em que as interrelaçóes com a(s) cultura(s) social(ais) de referência e, particularmente, as culturas juvenis estão especialmente presentes. Esta tensão permeia em maior ou menor grau o cotidiano das escolas estudadas e, talvez, se possa afirmar que é constitutiva da dinâmica escolar.

Certamente o trabalho realizado abriu muitas perspectivas, tanto no nível da continuidade da linha de pesquisa, quanto no da busca de modos concretos de se trabalhar a prática pedagógica no sentido de que a sensibilidade pela valorização das relações entre educação e cultura(s) cresça entre nós e contribua para se recriar os processos de escolarização, no sentido de sua maior relevância acadêmica, político-social e cultural.

O segundo projeto integrado de pesquisa, intitulado "Educação intercultural e cotidiano escolar: Construindo caminhos", foi realizado de março de 1998 a fevereiro de 2000. Situou-se em continuidade à pesquisa anterior e teve por objetivo geral realizar um balanço crítico 
dos principais enfoques presentes na produção teórica sobre multiculturalismo e educação, situando a reflexão brasileira neste contexto, e identificar e estudar experiências educativas, no âmbito da educação formal, que tivessem claramente a questão multicultural como referência. A natureza das questôes propostas e sua abrangência exigiram um tratamento metodológico que articulasse um estudo, na perspectiva dos levantamentos bibliográficos, orientados a um balanço crítico da produção científica pertinente, com a realização de uma pesquisa de campo de natureza etnográfica.

O levantamento bibliográfico da literatura sobre o tema focalizou a produção da área a partir dos anos 80 e não teve a pretensão de ser exaustivo, tarefa hoje impossível de ser realizada. ${ }^{2}$

Quanto à pesquisa de campo, realizou-se um estudo de caso centrado no movimento "Pré-Vestibular para Negros e Carentes" (PVNC), que teve suas origens na Bahia e vem realizando atividades no Rio de Janeiro desde 1992, sendo este atualmente o local onde tem maior desenvolvimento, chegando a aproximadamente 70 núcleos. Esse movimento se propõe explicitamente a "ser um instrumento de conscientização, articulação e apoio à juventude negra e alavancar o processo de combate ao racismo e à discriminação do acesso da população pobre à universidade".

Analisando o contexto histórico-social de seu surgimento, é possível afirmar que a proposta do Pré-Vestibular para Negros e Carentes ${ }^{3}$ (PVNC) não apenas nasce em meio a uma série de tensões como também pretende ser uma forma de procurar dar resposta a elas.

Entre as tensões com as quais convive é possível destacar uma como radical: a presente entre, de um lado, a seletividade do acesso ao ensino superior, um dos efeitos da realidade de exclusão social, cultural e educacional de grupos sociais desfavorecidos, prioritariamente dos negros e, de outro, a forte demanda desses grupos pela democratização da educação, particularmente do ensino superior, e o reconhecimento pelo PVNC da legitimidade desta luta.

Neste contexto, por intermédio da criação de seus núcleos, promotores de pré-vestibulares comunitários, o projeto tem promovido a entrada em universidades públicas e particulares de um número significativo de universitários, em vários estados do país, oriundos das classes populares e, em geral, afro-descendentes.

Em momento algum o conhecimento e a discussão da realidade anteriormente apontada são negados aos alunos e alunas dos "Prés". Muito 
pelo contrário, os cursos não incentivam ilusões sobre a possível aprovação no vestibular de seus alunos e alunas, e tampouco a redução dos preconceitos existentes em relação a eles, caso venham a passar nesse exame. Os estudantes são incentivados a enfrentar a realidade competitiva e preconceituosa, característica do apartheid universitário brasileiro, buscando formas solidárias de encarar essa mesma realidade como fonte de motivação para que continuem lutando contra todas as situaçóes adversas que pesam sobre sua condição de "negro" e "carente".

Esta postura, no entanto, convive com tensões no interior da dinâmica do movimento e dos núcleos, uma vez que se faz necessário conviver lado a lado tanto com o clima de competição típico do processo seletivo, do qual o vestibular não é uma exceção, quanto com o clima de solidariedade, no qual os(as) alunos(as) se apóiam mutuamente e se sentem mais fortes por saberem que sua exclusão não é isolada, mas a realidade de milhões de negros e pessoas de baixa renda que sofreram e continuam sofrendo todo tipo de injustiça e preconceito em nossa sociedade.

Estas duas lógicas (a de adesão e a de resistência) se confrontam na concepção do PVNC. A lógica de adesão tende a reforçar o papel central atribuído aos exames vestibulares, concebendo as diferentes dimensões do projeto de forma subordinada à finalidade mais imediata de ingresso no ensino superior. Nesta lógica, mais importante do que questionar a atual concepção do vestibular, trata-se de adequar-se às suas exigências. Dessa forma, por exemplo, professores(as) aceleram o conteúdo das matérias, ou privilegiam correçôes de questões de provas de vestibulares passados, deixando de lado frequentemente discussões de interesses mais amplos, ou, em outra perspectiva, a coordenação e os(as) alunos(as) enfatizavam e dedicavam muito tempo e energia a recorrer a vários meios para conseguir dinheiro ou isenções para garantir as inscrições de todos(as) nos exames, entre outros exemplos.

Quanto à lógica de resistência, também presente, ela tende a imprimir um movimento de distanciamento em relação ao vestibular, ou melhor, um movimento de conformidade crítica. Joga-se com as regras do jogo em vigor sem, no entanto, deixar de questioná-las. Nesta perspectiva, resiste-se à lógica competitiva e individualista que caracteriza os exames vestibulares e introduz-se outros conteúdos que não estão direta nem necessariamente orientados a esses exames.

No entanto, a pressão da lógica de adesão ao ritmo de trabalho de preparação para o vestibular imposta aos docentes, colaboradores e alunos(as), 
dificulta a realização de atividades e a discussão de temáticas que possam ir além do programa cobrado no vestibular, como sugere a carta de princípios do PVNC, ou seja, a criação de um espaço público de elaboração de propostas e discussão política sobre justiça, democracia e educação, assim como a defesa de posturas contrárias a qualquer tipo de discriminação racial. A disciplina Cultura e Cidadania tenta minimizar essa tensão constituindo-se como um espaço para se discutir questões gerais de cultura, política, saúde, educação etc. Contudo, seja pela maneira como é ministrada em vários núcleos, sob a forma de palestras realizadas por diferentes especialistas convidados, seja pela pressão da discussão de temas mais ligados aos conteúdos solicitados pelo vestibular, ela também possui suas tensões próprias, e nem sempre consegue trabalhá-las de modo adequado e produtivo.

A própria justificativa da introdução da disciplina Cultura e Cidadania no currículo do PVNC traduz essa tensão: de um lado, a lógica de adesão tende a justificar a presença dessa disciplina como facilitadora dos temas dos exames de redação presentes no vestibular; de outro, a força da argumentação da lógica de resistência para a implementação dessa disciplina consiste na importância do papel desempenhado pela natureza específica dos conteúdos administrados por ela no processo de conscientização política e de construção da identidade sócio-cultural dos(as) alunos(as) do PVNC.

Esta tensão constitutiva do PVNC foi muito bem traduzida em um slogan de uma camiseta confeccionada por um dos núcleos observados, que diz o seguinte: "Chegará o dia em que o PVNC não mais existirá, pois ele terá alcançado o seu objetivo maior: uma educação digna e igualitária para todos".

$\mathrm{Na}$ análise da prática pedagógica do PVNC, utilizamos como referência fundamental o modelo proposto por Banks para a construção de um currículo multicultural. Neste sentido, cinco critérios marcaram o nosso olhar durante a observação das aulas das diferentes disciplinas: o grau de integração dos conteúdos, o processo de construção de conhecimentos, a redução do preconceito, a pedagogia da eqüidade e o "empoderamento" dos diferentes grupos. O fato de o PVNC atender a uma população com características bem definidas, traduzidas no próprio nome dado a esta experiência educativa, faz com que o grupo de alunos(as) possua um certo grau de homogeneidade, o que exigiu uma adequação do modelo à realidade observada. Assim, a aplicação de alguns critérios se tornou mais difícil do que a de outros, quando utilizados de forma isolada em cada disciplina, prestando-se muito mais para caracterizar esta experiência pedagógica como um todo. 
No que diz respeito à integração do conteúdo, foi possível observar que, apesar de os conteúdos específicos de algumas disciplinas oferecerem uma maior visibilidade sobre estas questóes e uma maior possibilidade para que essas disciplinas pudessem ser contempladas e devidamente exploradas - Literatura, Português, História e Geografia -, dois fatos parecem desempenhar um papel decisivo neste processo seletivo, se bem que em direções contrárias: a sensibilidade dos(as) professores(as) e dos(as) alunos(as) para estas questões e a expectativa do vestibular no final do ano letivo. O primeiro tende a intensificar o grau de integração e o segundo a limitá-lo. Esta tensão, apesar de em graus diferenciados, estava presente muitas vezes no seio de uma mesma disciplina, assim como de uma mesma aula.

Importa sublinhar que, no caso da disciplina Cultura e Cidadania, a aplicação deste critério não se coloca da mesma forma. A sua própria existência traduz uma modalidade de abordagem da questão da eletividade dos conteúdos escolares às avessas. Ao passo que a tendência mais comum no âmbito das disciplinas escolares tradicionais é a de minimizar a dimensão seletiva dos conteúdos trabalhados, Cultura e Cidadania, ao oferecer um espaço de discussão e reflexão sobre temas ou conteúdos que em geral não são contemplados nas disciplinas tradicionais, não apenas reconhece a dimensão seletiva de todo conhecimento escolar, como também se posiciona de forma explícita quanto aos critérios dessa seleção.

Estes resultados confirmam a afirmação de Banks de que esta dimensão da abordagem multicultural na sala de aula é apresentada como tendo maior relevância para professores(as) das áreas de ciências sociais e linguagem do que para os da área científica. No entanto, convém salientar que os indicadores observados são frágeis, mas podem representar um ponto de partida importante para que essa dimensão possa ser desenvolvida e mais explicitamente trabalhada. Quanto às disciplinas da área científica, segundo o mesmo autor, outras dimensôes do seu modelo são mais pertinentes para serem por elas trabalhadas.

Quanto à segunda dimensão do modelo de Banks, o processo de construção do conhecimento, nas observações realizadas, foi possível perceber que no trabalho dos(as) professores(as), principalmente das áreas sociais e relativas ao ensino de língua e literatura, esta preocupação se fez presente de modo esporádico e pouco trabalhado. No que diz respeito à subjetividade dos(as) alunos(as) e à forma como esta intervém no processo de construção do conhecimento, a tendência mais presente nas práticas pedagógicas foi a de considerá-los mais como consumidores de informação do que sujeitos ativos na produção do seu próprio conhecimento. 
Reduzir o preconceito é outra das dimensões que caracterizam uma educação multicultural, o que significa ter como um princípio básico o desenvolvimento nos(as) educandos(as) de uma postura racial e étnica positiva. Desenvolver um sentimento, uma atitude e um relacionamento positivo com outros grupos raciais e étnicos não é uma realidade dada. Ela deve ser construída, estimulada. Para uma educação multicultural, os(as) educandos(as) devem ser estimulados nesta direção.

Foi possível constatar em nossas observações que a intenção do PVNC prevê uma formação crítica dos(as) jovens que passam pelos núcleos do movimento, o que se efetiva - ainda que de maneira frágil e nem sempre constante - em algumas aulas, nas reunióes dos núcleos e nas assembléias do movimento, nas discussões informais, nas aulas de Cultura e Cidadania, nas brincadeiras, na vigilância à linguagem "politicamente correta", na promoção da auto-estima racial etc. Os professores e professoras mais engajados na proposta do PVNC e, principalmente, as(os) coordenadoras(es) dos núcleos buscavam despertar os(as) alunos(as) para uma visão crítica sobre a situação do negro no Brasil.

Os dados coletados permitem afirmar que, no que diz respeito à dimensão de redução do preconceito, este movimento incorpora - de maneira muito clara em sua proposta e de maneira ainda incipiente na dinâmica da sala de aula - esta preocupação que, segundo Banks (1999), é inerente às propostas de educação multicultural.

Quanto à pedagogia da eqüidade, os diferenciados modos de promover um ensino cooperativo têm sido uma das estratégias mais utilizadas pelos professores que querem incorporar a abordagem multicultural para favorecer este processo. Nesta categoria, quando muito puderam ser detectados alguns indicadores de que, eventualmente, determinados professores procuram utilizar estratégias de diversificação para a facilitação da aprendizagem. No entanto, esta é uma temática ainda pouco trabalhada entre nós, particularmente no que diz respeito à diversidade cultural, mas que é de especial importância para a dinamização de uma pedagogia da eqüidade. A consciência desta perspectiva praticamente não foi evidenciada nas observações realizadas, aparecendo apenas de modo muito tênue alguns indicadores de diversificação no plano da aprendizagem dos conteúdos, sem uma relação explícita com dimensões socioculturais.

Segundo Banks (1999), uma prática escolar que promova $o$ "empoderamento" de diferentes grupos deve estar atenta ao processo de reconstrução da cultura e da organização escolar, de maneira tal que 
os(as) estudantes de diferentes grupos étnicos, de gênero e classes sociais façam uma experiência de igualdade educacional e dos próprios processos de "empoderamento". Esta é uma dimensão da educação multicultural que envolve uma concepção da escola como mobilizadora de mudança social a partir do próprio ambiente educacional. Sendo assim, parte-se da convicção de que todos os estudantes podem lograr níveis adequados de aprendizagem, independentemente de sua etnia, gênero ou classe social. Lograr um clima educacional nesta perspectiva é uma meta importante para práticas educacionais que desejem criar uma cultura escolar e uma estrutura social que seja "empoderadora" dos estudantes de diferentes grupos, especialmente daqueles oriundos de setores sociais e culturais marginalizados.

Partindo desta categorização, podemos considerar que o PVNC tem esta como uma de suas preocupaçôes e a incorpora de maneira significativa mas não com a mesma intensidade por parte de todos os professores. A dimensão do "empoderamento" manifesta-se de diferentes maneiras, seja desenvolvendo de modo constante a auto-estima dos alunos e alunas, promovendo assim uma consciência de que todos podem aprender independentemente de sua condição social, de gênero ou étnica, seja propiciando entre os(as) alunos(as) e os(as) professores(as) uma prática democrática, na qual a participação e o envolvimento de todos(as) é uma realidade buscada e bastante alcançada, dentro dos limites deste processo.

Tendo por base o modelo de Banks, é possível afirmar que as dimensões mais trabalhadas nas salas de aula dos núcleos observados foram as relacionadas ao "empoderamento" e à redução de preconceito. Essas são dimensões presentes no cotidiano dos núcleos e reforçadas pelos(as) coordenadores(as) e professores(as), não sempre com o mesmo grau de consciência, compromisso e intensidade. Os atores mais envolvidos no movimento como um todo, professores(as), coordenadores(as) e alunos(as), revelaram maior envolvimento nesta perspectiva.

Quanto às dimensões menos presentes nas salas de aula - integração dos conteúdos e processo de construção do conhecimento -, relacionamse com questôes inerentes à seleção dos conteúdos escolares, constituição do conhecimento escolar e transposição didática, assim como às questôes epistemológicas relativas à própria natureza do conhecimento e sua historicidade. Constituem preocupaçôes importantes para se trabalhar a cultura escolar na perspectiva multicultural. Sua incidência no dia-a-dia dos núcleos observados revelou-se escassa e frágil, em geral no âmbito das ciências sociais e do ensino de língua e literatura. A própria natureza de um curso pré-vestibular certamente opera como um inibidor desta 
preocupação. No entanto, perguntamo-nos se sua quase ausência é devida exclusivamente a este fator ou se o nível de consciência desta problemática está ainda muito pouco presente entre os professores e professoras do PVNC em geral. Poder-se-ia esperar que educadores engajados num movimento de natureza identitária tivessem mais sensibilidade para estas questôes.

Certamente a introdução da perspectiva multicultural no dia-adia das escolas e da sala de aula, provoca muitas questôes pedagógicas relacionadas com a seleção dos conteúdos escolares, as estratégias de ensino, o relacionamento professor(a)-aluno(a) e aluno(a)-aluno(a), o sistema de avaliação, o papel do(a) professor(a), a organização da sala de aula, as atividades extra-classe, a relação escola/comunidade, entre outras.

Tanto na análise da documentação relativa ao PVNC, quanto nas observações e entrevistas realizadas, foi possível detectar que a sensibilidade para as questões especificamente pedagógicas ainda está pouco presente nas preocupações do movimento, sendo raros os espaços de reflexão sobre sua problemática.

Outro aspecto de especial importância para a proposta do PVNC diz respeito à disciplina Cultura e Cidadania. Ela é reconhecida pelos diferentes atores como de particular relevância para o projeto. É afirmada como sendo sua alma, sua espinha dorsal. Sua organização e desenvolvimento é de responsabilidade das coordenações dos núcleos, havendo uma enorme variedade de modos concretos de desenvolvê-la, não parecendo haver uma base comum. Talvez fosse importante promover uma reflexão sobre sua organização, os temas a serem enfatizados, as metodologias a serem privilegiadas etc., evitando-se assim a improvisação e que possa ficar reduzida a uma série de palestras, sem maior articulação nem um planejamento orgânico.

Uma questão que emergiu durante a pesquisa de campo diz respeito à articulação da formação para a cidadania com as questões culturais. Não se pode dar por óbvia esta interlocução. De fato, ela pode assumir diferentes configurações, indo da mera justaposição, sendo a dimensão política e a cultural concebidas como pólos independentes, sem nenhuma articulação, até uma perspectiva integradora na ótica do que Chauí (1999) denomina cidadania cultural.

As observações e entrevistas realizadas permitiram perceber que, na prática, predomina uma abordagem de justaposição, com ênfase em temas relacionados à dimensão política e ao exercício da cidadania. Tratando-se de uma questão nuclear para o desenvolvimento do projeto, 
consideramos especialmente importante que haja uma reflexão coletiva sobre a articulação cidadania/cultura e que se vá construindo um modo próprio, flexível, mas com um enfoque comum, de trabalhá-la no desenvolvimento da disciplina Cultura e Cidadania, assim como no cotidiano dos núcleos.

O Pré-Vestibular para Negros e Carentes constitui-se em uma experiência educacional que busca inserir na universidade alunos(as) que, por conta própria, dificilmente o conseguiriam em razão dos processos excludentes que têm sofrido ao longo de suas histórias individuais e sociais. Sem dúvida alguma o PVNC é um importante veículo no sentido da inclusão dos grupos marginalizadas, como os negros e os grupos populares de baixa renda. Diante desta realidade, questionamo-nos sobre como o PVNC se situa em relação às políticas de ação afirmativa.

Consideramos que as ações afirmativas podem ser analisadas por dois prismas: num sentido restrito e num sentido mais amplo. No primeiro caso, as ações afirmativas são apontadas como políticas públicas temporárias, promovidas por parte do Estado tanto em seu Poder Legislativo quanto Executivo, que objetivam a promoção da igualdade entre os grupos sociais, levando em consideração desvantagens sofridas ao longo da História, como aponta Melo (1998). Assim, as medidas de ação afirmativa configuram-se como uma alternativa para o acesso à escolaridade e a cargos públicos e privados e até mesmo à representação parlamentar por parte de grupos étnicos, de gênero etc. (Melo, 2000).

A segunda possibilidade de interpretação das ações afirmativas seria encará-las como medidas amplas, não necessariamente atreladas às políticas públicas, medidas estas que visam à justiça distributiva, ou seja, que buscam a democratização da sociedade e são promovidas em diferentes espaços sociais, como movimentos populares, por exemplo.

Se considerarmos a definição na qual as ações afirmativas seriam um conjunto de medidas, legislativas ou administrativas, que tendem a defender ou incentivar grupos marginalizados e discriminados, não podemos considerar o PVNC como uma ação afirmativa em si mesmo, uma vez que se trata de um movimento de educação popular que não recebe apoio ou proteção de leis que facilitem o acesso de alunos(as) oriundos do PVNC às universidades.

Talvez algumas medidas de ação afirmativa, em sentido mais restrito, mediadas pelo movimento sejam as lutas por isenção das taxas para inscrição no vestibular e para a concessão de bolsas de estudo aos alunos e alunas oriundos do PVNC nas instituiçóes de ensino superior 
particulares. Neste caso, esta luta se dá quando o(a) aluno(a) já ingressou na universidade única e exclusivamente pelos seus próprios esforços e não por políticas que facilitem a inserção do(a) aluno(a) negro(a) e de baixa renda nos quadros universitários.

Em uma perspectiva mais ampla, o PVNC pode ser interpretado como ação afirmativa, uma vez que, ao buscar inserir as camadas desfavorecidas na universidade e, ao mesmo tempo, considerar a importância de uma formação crítica e orientada à afirmação das identidades culturais, está operando na lógica da justiça distributiva, oferecendo possibilidades de oportunidades que levem os(as) alunos(as) a estarem mais próximos da igualdade de oportunidades educacionais. Na qualidade de ação afirmativa, o Pré-Vestibular para Negros e Carentes parece-nos um importante instrumento de "empoderamento" de identidades socioculturais historicamente excluídas do ensino superior, e de um ensino de qualidade de maneira geral.

O PVNC, além de preparar tecnicamente os(as) alunos(as) para o vestibular, teria um importante papel no sentido de "empoderá-los" de forma que estes se percebam como importantes agentes sociais, para que possam atuar no mundo social, cientes de suas potencialidades, de seus direitos e de seu poder.

A categoria "empowerment", muitas vezes traduzida como "empoderamento", tem sido ainda pouco utilizada por autores brasileiros, sendo especialmente difundida nos debates em relação à questão de gênero. Sen (1998) sustenta que termos como "participação" e "empoderamento" são palavras cuja origem pode estar situada em uma linguagem crítica dos paradigmas de desenvolvimento dominantes nas décadas de 1960 e 1970. Tais expressões têm sido utilizadas, ainda que não tenham o mesmo significado, por agências de financiamento, governos e organizações da sociedade civil. Como ressalta Sen (1998), quando atores sociais com ideologias, enfoques e práticas muito variados buscam encontrar um conjunto comum de conceitos, existe uma considerável falta de clareza e certa confusão acerca de seus significados reais. Assim, ao utilizarmos o conceito de "empoderamento" é indispensável clarificar o que entendemos por este. Para Sacavino (1998):

Empoderamento significa que cada cidadão/ã deve descobrir, construir e exercer no cotidiano, individual e coletivamente, o poder que tem pela própria condição de cidadania. É importante que cada grupo, movimento, associação descubra seu poder e o exerça. Constitui uma tarefa educativa fundamental 
colaborar na construção do empoderamento dos grupos tradicionalmente marginalizados e hoje excluídos: indígenas, negros, mulheres, jovens, desempregados, analfabetos, sem terra, sem casa etc.; todos esses grupos aos que o sistema dominante faz crer que não têm poder, porque o poder está concentrado principalmente exclusivamente nos políticos, empresários e investidores. (P. 83)

As ações afirmativas são estratégias orientadas para o "empoderamento". Tanto as concebidas no sentido restrito quanto as que se situam num enfoque amplo desenvolvem estratégias de fortalecimento do poder de grupos marginalizados, para que estes possam lutar pela igualdade de condições de vida em sociedades marcadas por mecanismos estruturais de desigualdade e discriminação.

O Pré-Vestibular para Negros e Carentes entende que para acelerar as transformações sociais é preciso que sejam formuladas políticas de ação afirmativa, para que se corrijam as marcas da discriminação construída ao longo da História, a exemplo de países como Alemanha, Rússia e EUA. Neste sentido, defende que sejam aprovadas leis que vinculem pelo menos $50 \%$ das vagas nas universidades públicas aos alunos e alunas provenientes da rede pública de ensino.

Assim, consideramos que as estratégias de "empoderamento" construídas no interior do PVNC possam ser um importante instrumento de pressão social para que medidas de ação afirmativa no sentido de políticas públicas sejam implementadas em relação ao ingresso na universidade ou no mercado de trabalho.

$\mathrm{Na}$ Carta de Princípios do Pré-Vestibular para Negros e Carentes está claramente formulado o seu compromisso com uma proposta educativa e um projeto de sociedade que promovam processos de democratização onde as lutas por maior igualdade no plano socioeconômico e por melhores condiçôes de vida para os grupos populares estejam associadas às questôes relativas às identidades culturais e colaborem para a superação do racismo, da discriminação de gênero, da discriminação cultural $e$, de forma geral, das desigualdades sociais. Sendo assim, fica claramente explicitada a intencionalidade de se trabalhar na perspectiva da educação multicultural.

O multiculturalismo, como já afirmamos, é um fenômeno complexo, contraditório e atravessado por múltiplas questóes, concepçōes e tensões. Entre nós trata-se de uma preocupação que recentemente vem adquirindo maior visibilidade e vão surgindo vários grupos, tanto nos espaços acadêmicos quanto nos movimentos sociais, preocupados com a discussão teórica e as implicações práticas das suas propostas. 
Nesta perspectiva, o PVNC pode ser considerado um dos pioneiros, já que não são muitas as experiências atualmente em realização que explicitam claramente e de modo orgânico o enfoque multicultural.

Certamente preocupações presentes no PVNC, como consciência da identidade cultural e social, autoconceito e auto-estima, "empoderamento", combate ao racismo, ao preconceito e à discriminação cultural e social, ação afirmativa, respeito à diversidade étnico-cultural, democratização da educação e da sociedade, entre outras, são características importantes da perspectiva multicultural. No entanto, também o são as questões relativas ao modo de produção e socialização do conhecimento, à tensão relativismo-universalismo e seleção de conteúdos curriculares, às "vozes" ausentes dos conteúdos escolares, à crítica e elaboração de materiais didáticos, à formação de professores etc.

$\mathrm{Na}$ pesquisa de campo realizada, em várias ocasiōes foi possível evidenciar, nas categorias de Banks (1999), uma abordagem multicultural que, do ponto de vista cognitivo, é aditiva, incluindo-se alguns temas específicos em diversas disciplinas, e, principalmente, por meio da introdução da disciplina Cultura e Cidadania. O desafio da perspectiva multicultural está em que todo o currículo possa ir sendo transformado a partir desta preocupação e não se restrinja esta sensibilidade a determinados temas e/ou disciplinas. Nas observações realizadas também se evidenciaram aspectos inerentes ao enfoque da ação social, articulandose a dinâmica da sala de aula e do núcleo com uma incidência social, manifestada em compromissos com açóes comunitárias e com a problemática da democratização, do preconceito e da discriminação na sociedade em geral.

Entre as tendências inerentes ao multiculturalismo situa-se a educação intercultural. No caso do PVNC, a ênfase é colocada na construção de identidades particulares, silenciadas e excluídas da sociedade. A principal preocupação é o "empoderamento" destes sujeitos sociais do ponto de vista educativo e social. Podemos considerar que estas são condiçóes importantes para o desenvolvimento da interculturalidade. Para um relacionamento lúcido e crítico com o outro, o diferente, é importante a construção consciente da própria identidade cultural, assim como um autoconceito e uma auto-estima positivos, do ponto de vista pessoal, social e cultural.

No entanto, o confronto entre os "diferentes", quando trabalhado do ponto de vista educativo, é um fator importante na tomada de consciência e construção da própria identidade, no plano pessoal e 
coletivo. Articular o reconhecimento entre iguais e o sentido de pertença a um grupo específico com a interrelação com os "diferentes", reconhecendo-os como tais e desenvolvendo a capacidade de um diálogo crítico, é uma preocupação fundamental da educação intercultural. Esta perspectiva articuladora não nega os conflitos e supóe lutar contra toda forma de preconceito e discriminação, favorecendo dinâmicas sociais orientadas à afirmação de uma sociedade democrática e igualitária.

Foi possível constatar, de modo especial nos depoimentos de alguns atores, que a interculturalidade está no horizonte do PVNC e que, neste sentido, não se trata de um movimento que favoreceria um multiculturalismo fechado e sim uma perspectiva aberta, orientada à afirmação de uma interculturalidade crítica, orientada a favorecer a democratização da sociedade.

Como desdobramento dessa pesquisa, tendo presente que em várias entrevistas realizadas com universitários(as) ex-alunos(as) do PVNC, apesar de não ter sido este o foco do trabalho, emergiram em muitos momentos o "estranhamento", a dificuldade de lidar com a cultura universitária, a experiência de discriminação e racismo na vida universitária, a rigidez das práticas pedagógicas e a dificuldade dos professores de lidar com a pluralidade cultural, apresentamos ao CNPq um terceiro projeto integrado de pesquisa - "Universidade, diversidade cultural e formação de professores" -, que focaliza fundamentalmente as relações entre diversidade cultural e pedagogia universitária, de modo especial nos cursos de licenciatura. Esse projeto teve início em 1999 e se encontra na fase final de análise dos dados.

A pesquisa de campo foi realizada em uma universidade comunitária, reconhecida nacionalmente pela sua qualidade acadêmica e científica, que vem desenvolvendo desde 1994 uma política com o objetivo de favorecer o acesso de estudantes de camadas populares aos seus cursos de graduação, a maioria dos quais é de afro-descendentes. Esses alunos e alunas, uma vez aprovados nos exames vestibulares, candidatam-se a uma bolsa de "ação social" - em outubro de 2001 a universidade contava 436 bolsistas de "ação social" -, bolsas integrais não-reembolsáveis que garantem a gratuidade na universidade. Esses alunos e alunas também podem aceder a outros apoios que visam a oferecer condições básicas necessárias à vida universitária. A maioria desses bolsistas está vinculada ao movimento "Pré-Vestibular para Negros e Carentes" (PVNC), havendo também alunos(as) vinculados(as) a outros pré-vestibulares comunitários. 
Concentramos o nosso estudo em três departamentos, entre os que têm maior número desses estudantes e oferecem cursos de licenciatura. Numa primeira aproximação, analisamos o currículo explícito desses cursos, as ementas e os programas das disciplinas por eles oferecidas, com a finalidade de identificar alguns elementos que permitissem vislumbrar uma preocupação com temáticas que poderiam ser incluídas no âmbito do multiculturalismo. Estamos conscientes dos limites desta abordagem, mas consideramos que ela pode oferecer alguma contribuição para identificar uma intencionalidade explícita. A análise ainda não está terminada, mas é possível afirmar que o número das disciplinas que explicitam, mesmo de um modo amplo, uma preocupação sensível às questôes colocadas pelo multiculturalismo, é bastante reduzido. Esta afirmação é confirmada pelos depoimentos dos(as) alunos(as), os quais, em geral, declararam que as questôes relativas à diversidade cultural e à diferença somente estavam presentes em algumas disciplinas e de forma esporádica e pontual. Também afirmaram que, mesmo quando eram discutidas em sala de aula, existia uma distância muito grande entre o tratamento acadêmico desta problemática, a afirmação da importância de se levar em consideração esta realidade no ensino fundamental e médio, e a própria dinâmica da sala de aula que ignorava a diversidade cultural nela presente. A sala de aula era vivenciada pelos estudantes entrevistados como um espaço padronizado, rígido, homogêneo e monocultural, que não dava abertura para a manifestação das diferenças ou, quando esta realidade acontecia, assumia muitas vezes uma dimensão fortemente agressiva e mobilizadora de dinâmicas de exclusão ou guetificação. Situações de preconceito, discriminação e racismo foram explicitadas, tanto nas relações entre alunos e alunas, quanto nas dos(as) alunos(as) com os(as) professores(as).

A entrada na universidade, na qual foi realizado esse estudo, de um número significativo de alunos oriundos de camadas populares e afro-descendentes é vista por um número significativo e diferenciado de atores universitários, tanto entre alunos(as) quanto professores(as), como apresentando muitos desafios e mesmo como uma ameaça à qualidade do ensino na instituição em que foi realizado o estudo. Tais alunos e alunas sentem-se muitas vezes discriminados e desenvolvem estratégias pessoais e grupais, nem sempre bem-sucedidas, de resistência e conquista do espaço universitário. Iniciativas de ação afirmativa promovidas pela universidade, orientadas à permanência desses alunos e alunas na vida universitária, têm sido de especial importância e provocado diferentes reações entre o corpo docente e discente, tanto de apoio como de rejeição. 
Quanto aos professores e professoras entrevistados, estes assumem diferentes posições diante do tema: há os que se aproximam mais de uma perspectiva universalista, centrada no conteúdo cognitivo e num tratamento "igual" a todos os alunos e alunas, e silenciam a problemática da diferença aos que, conscientes das questôes provocadas pela heterogeneidade sociocultural dos(as) alunos(as), põem ênfase num enfoque de caráter compensatório, procurando um tratamento adequado para as "deficiências" que alunos e alunas oriundos dos pré-vestibulares comunitários trazem no que diz respeito ao domínio de habilidades cognitivas fundamentais para a vida acadêmica, como se somente eles apresentassem esta problemática. Há também aqueles, não muito numerosos, que revelam maior sintonia com uma perspectiva mais aberta, admitindo a necessidade de uma certa reconceitualização da seleção dos conteúdos e do tratamento pedagógico, em função da sua adequação à realidade dos diferentes sujeitos socioculturais e a suas especificidades, assim como da própria relevância para as diferentes áreas do conhecimento das questóes suscitadas pelo multiculturalismo. O que fica claramente evidente é a dificuldade dos(as) professores(as), e da universidade em geral, de lidarem com as questões epistemológicas, pedagógicas e didáticas na perspectiva multicultural e de romperem com uma representação uniforme de aluno(a), que é passada também aos futuros professores e professoras do ensino fundamental e médio.

\section{Considerações finais}

Certamente, a introdução da perspectiva multicultural no dia-adia das escolas e na formação de professores não pode limitar-se a questões de caráter político-ideológico, de sociologia e antropologia da educação e de princípios orientadores da teoria curricular. Estas dimensões são imprescindíveis, mas insuficientes. Esta perspectiva provoca muitas questôes relacionadas com o próprio papel social, cultural e científico da universidade, assim como questiona a pedagogia universitária vigente.

No Brasil, a reflexão sobre esta temática tem sua especificidade e vai penetrando lentamente na vida acadêmica. No cotidiano escolar ainda está muito pouco presente. Nos anos que levamos aprofundando esta temática, não foi nada fácil identificar propostas educativas concretas que tenham uma referência explícita a questões que podem ser situadas no âmbito das preocupações multiculturais. A maioria das escolas em que de alguma forma o tema penetra se limita a adicionar alguns conteúdos que têm que ver com a pluralidade cultural, a ressignificar comemoraçóes 
e outras práticas escolares esporádicas nesta perspectiva ou a adotar uma perspectiva assimilacionista e/ou compensatória. Em geral, predomina uma abordagem que não afeta a globalidade do currículo, não desenvolve processos de construção de identidades culturais em que se fortaleçam a auto-estima e o autoconceito dos alunos provenientes de grupos excluídos e discriminados, nem se promove o seu "empoderamento".

No caso do PVNC e de outros movimentos sociais de caráter identitário, a ênfase é colocada nos processos de "empoderamento" e combate ao racismo e à discriminação. No entanto, os aspectos relativos às questões epistemológicas e pedagógicas praticamente não são trabalhados.

No que diz respeito à universidade, a cultura acadêmica apresenta especial dificuldade de lidar com a diferença. São as políticas de ação afirmativa, ainda incipientes entre nós e objeto de grandes controvérsias, que incidem mais fortemente nesta problemática, mas, em geral, estão orientadas a favorecer o acesso de determinados grupos excluídos à universidade, especialmente aqueles oriundos das camadas populares e afro-descendentes, e privilegiam medidas de caráter socioeconômico, não incidindo nas dimensões científica e pedagógica da vida universitária.

Quanto aos cursos de formação de professores, esses abordam alguns temas geralmente de modo episódico e de acordo com as opções de cada professor(a), mas a questão multicultural ainda não é assumida como um dos princípios orientadores da formação docente, inicial e continuada.

Consideramos que, para que estas questôes possam ser mais trabalhadas na educação brasileira, é necessário desvelar o "mito da democracia racial”, tão arraigado no nosso imaginário social, para que sejamos capazes de assumir o caráter discriminador, hierarquizador, autoritário e de negação do "outro" da nossa sociedade, tão presente entre nós. Nossa educação tem características fortemente monoculturais e privilegia uma perspectiva universalista vinculada à visão iluminista da realidade.

Por outro lado, somente assumindo de modo consciente e crítico os processos de hibridização cultural presentes na sociedade brasileira e favorecendo o diálogo intercultural seremos capazes de promover processos educacionais que articulem igualdade e diferença, universalismo e relativismo e globalização e pluralidade cultural em nosso País.

A interculturalidade aposta na relação entre grupos sociais e étnicos. Não elude os conflitos. Enfrenta a conflitividade inerente a essas relações. 
Favorece os processos de negociação cultural, a construção de identidades de "fronteira", "híbridas", plurais e dinâmicas, nas diferentes dimensões da dinâmica social.

A perspectiva intercultural quer promover uma educação para o reconhecimento do "outro", para o diálogo entre os diferentes grupos sociais e culturais. Uma educação para a negociação cultural. Uma educação capaz de favorecer a construção de um projeto comum, pelo qual as diferenças sejam dialeticamente integradas. A perspectiva intercultural está orientada à construção de uma sociedade democrática, plural, humana, que articule políticas de igualdade com políticas de identidade (Santos, 2001).

Para terminar este artigo, que pretendeu unicamente levantar questôes e inquietudes, gostaríamos de retomar uma questão que nos parece nuclear: a perspectiva multicultural constrói-se na tensão entre os movimentos sociais e a academia. Coloca-nos no horizonte da afirmação da dignidade humana num mundo que parece não ter mais esta convicção como referência radical.

Estas palavras do subcomandante Marcos (2001), representante privilegiado de um movimento em que igualdade e identidade mutuamente se exigem, poéticas e militantes, especialmente estimulantes para as nossas buscas cotidianas, pessoais e coletivas, intelectuais e políticas, parecem-nos especialmente significativas e oportunas a situarnos no horizonte utópico que alimenta e inspira esta perspectiva:

A Dignidade exige que sejamos nós mesmos.

Mas a Dignidade não é somente que sejamos nós mesmos.

Para que haja Dignidade é necessário o outro.

E o outro só é outro na relação conosco.

A Dignidade é então um olhar.

Um olhar a nós mesmos que também se dirige ao outro olhando-se e olhando-nos. A Dignidade é então reconhecimento e respeito.

Reconhecimento do que somos e respeito a isto que somos, sim, mas também reconhecimento do que é o outro e respeito ao que ele é.

A Dignidade então é ponte e olhar e reconhecimento e respeito.

Então a Dignidade é o amanhã.

Mas o amanhã não pode ser se não é para todos, para os que somos nós e para os que são outros.

A Dignidade é então uma casa que nos inclui e inclui o outro.

A Dignidade é então uma casa de um só andar, onde nós e o outro temos nosso próprio lugar, isto e não outra coisa é a vida, e a própria casa. 
Então a Dignidade deveria ser o mundo, um mundo que tenha lugar para muitos mundos.

A Dignidade então ainda não é .

Então a Dignidade está por ser.

A Dignidade então é lutar para que a Dignidade seja finalmente o mundo.

Um mundo onde haja lugar para todos os mundos.

Então a Dignidade é e está por construir.

É um caminho a percorrer.

A Dignidade é o amanhã.

Recebido e aprovado em junho de 2002.

\section{Notas}

1. Os nomes utilizados neste trabalho são fictícios.

2. Ver V. M. F. Candau (Org.), Sociedade, educação e cultura(s): Questôes e propostas, Rio de Janeiro: Vozes, 2002.

3. O termo "carente" suscita muitas discussões, tanto no interior do movimento como por diferentes agentes sociais, e tem para seus organizadores exatamente esta intenção de provocar e suscitar o debate.

\section{Referências bibliográficas}

BANKS, J. Multiethinic education: Theory and practice. $3^{\text {a }}$ ed. Boston: Allyn and Bacon, 1994.

An introduction to multicultural education. 2a ed. Boston: Allyn and Bacon, 1999.

BANKS, J.; BANKS, C. Multicultural education: Issues and perspectives. $2^{\text {a }}$ ed. Boston: Allyn and Bacon, 1997.

CANDAU, V.M.F. Educação escolar e cultura(s). Tecnologia Educacional, Rio de Janeiro: ABT, jul./ago. 1995, vol. 22, no 125.

. "Da didática fundamental ao fundamental da didática"; In: André, M.; Oliveira, M.R.N.S. Alternativas do ensino da didática. Campinas: Papirus, 1997a.

- "Pluralismo cultural, cotidiano escolar e formação de professores"; In: Candau, V.M.F. (Org.). Magistério: Construção cotidiana. Rio de Janeiro: Vozes, 1997b. 
- Mudanças culturais e redefinição do escolar: Tensões e buscas.

Contemporaneidade e Educação, IEC, Rio de Janeiro, 1997c.

. Interculturalidade e educação escolar; IX Endipe, Águas de Lindóia, 1998.

. (Org.). Reinventar a escola. Rio de Janeiro: Vozes, 2000a.

. "A Didática hoje: Uma agenda de trabalho"; In: CandaU, V.M.F. et al. Didática, currículo e saberes escolares. Rio de Janeiro: DP\&A, 2000b.

. (Org.). Sociedade, educação e cultura(s): Questôes e propostas Rio de Janeiro: Vozes, 2002.

CHAUÍ, M. Cidadania cultural. Novamerica, Rio de Janeiro, 1999, no 82.

DECLARAÇÃO Universal sobre a Diversidade Cultural. Unesco, Paris, 2001.

FORQUIN, J. Escola e cultura: As bases sociais e epistemológicas do conhecimento escolar. Porto Alegre: Artes Médicas, 1993.

O currículo entre o relativismo e o universalismo. Educação \& Sociedade, Campinas: CeDES, dez. 2000, vol. XXI, no 73.

GARCIA CANCLINI, N. Los estudios culturales de los 80 a los 90: Perspectivas antropológicas y sociológicas en América Latina. Punto de Vista, San José de Costa Rica, set. 91, nº 90.

. Consumidores e cidadãos: Conflitos multiculturais da globalização. Rio de Janeiro: EdUFRJ, 1995.

. Culturas híbridas. São Paulo: Edusp, 1997.

. La globalización imaginada. Buenos Aires: Paidós, 1999.

GARCIA CASTAÑO, F.J.; PULIDO, R.A.M.; MONTES del CASTILLO, A. La educación multicultural y el concepto de cultura. Revista Iberoamericana de Educación, Organización de los Estados Iberoamericanos para la Ciencia y la Cultura, Colômbia, 1997, $\mathrm{n}^{\mathrm{o}} 13$.

HALL, S. A identidade cultural na Pós-Modernidade. Rio de Janeiro: DP\&A, 1997a. 
A centralidade da cultura: Notas sobre as revoluçôes de nosso tempo. Educação e Realidade, Porto Alegre, 1997b, vol. 22, no 2.

MARCOS (subcomandante). La marcha del color de la tierra. (Comunicados, cartas y mensajes del Ejército Zapatista de la Liberación Nacional del 2000 al 2 de abril del 2001) México: Rizoma, 2001.

McLAREN, P. Multiculturalismo crítico. São Paulo: Cortez, 1997.

Multiculturalismo revolucionário: Pedagogia do dissenso para o novo milênio. Porto Alegre: Artes Médicas, 2000.

MELO, C. Ação afirmativa. Monografia apresentada ao Departamento de Direito da PUC-Rio para obtenção do título de Bacharel em Direito, 1998.

Ação afirmativa e realidade brasileira. Novamerica, Rio de Janeiro, mar. 2000, no 85 .

PARÂMETROS Curriculares Nacionais. Brasília: Ministério de Educação e do Desporto, 1997.

PEREZ GOMEZ, A.I. La cultura escolar en la sociedad posmoderna. Cuadernos de Pedagogía, Barcelona, nov. 1993.

SACAVINO, S. Democracia y ciudadania en el nuevo orden mundial globalizado. Trabalho apresentado no seminário "Hacia una América Latina Diferente. Democracia, Derechos Humanos y Educacion”, Cochabamba, Bolívia, 1998.

SANTOS, B.S. As tensões da Modernidade. Forum Social Mundial, Biblioteca das alternativas, 2001 (htpp//www.forumsocialmundial.org.br).

SEN, G. El empoderamiento como un enfoque a la pobreza. In: Arriagada, I.; Torres, C., Gênero e pobreza: Nuevas dimensones, Santiago: Isis Internacional, 1998. 